\title{
Levels of a neurotoxic alkaloid in a species of low larkspur
}

WALTER MAJAK AND MICHAEL ENGELSJORD

\section{Abstract}

A survey of the levels of the neurotoxic diterpenoid alkaloid methyllycaconitine (MLA) in low larkspur (Delphinium nuttallianum Pritz.) was conducted at 4 diverse rangeland sites in southern British Columbia. Freeze-dried plant samples representing 3 stages of growth over 2 growing seasons were analyzed for MLA by high pressure liquid chromatography. Significant differences were found among experimental sites $(P<0.001)$ with higher levels of MLA $>\mathbf{0 . 2 \%}$ on a dry weight basis) being associated with sites at higher elevations (900-975 m). At one site, an exceptional level of MLA $(\mathbf{0 . 3 \%})$ was observed during the flower bud stage of growth but in general the alkaloid levels remained fairly constant with advancing stages of growth. Measurement of the MLA concentrations in different plant parts revealed that reproductive parts contained higher levels of MLA than vegetative parts and this may well explain the increased toxicity of the upper portions of the plant.

Key Words: Delphinium nuttallianum, diterpenoid alkaloids, methyllycaconitine, livestock poisoning

Plants of the genus Delphinium, commonly known as larkspur, are one of the major causes of poisoning in range cattle of North America (Cronin and Nielsen 1978). A particular species of low larkspur, Delphinium nuttallianum Pritz., occurs from northern California and Colorado in the U.S. to the interior of British Columbia in Canada (Hitchcock and Cronquist 1964). In B.C., it is generally found on grasslands at elevations up to $1,500 \mathrm{~m}$. Appearing early in spring, often before most of the grasses, it can be palatable but poisonous to cattle (Looman et al. 1983). Recently the toxicity of $D$. nuttallianum (Majak et al. 1987), as well as that of 2 related species, D. brownii Rydb. and D. bicolor Nutt. (Aiyar et al. 1979, Kulanthaivel et al. 1986), was attributed to the diterpenoid alkaloid, methyllycaconitine (MLA). This alkaloid is a potent neuromuscular blocking agent in cattle (Nation et al. 1982) and it also appears to be a naturally occurring insecticide (Jennings et al. 1986). A method was recently developed to isolate and precisely determine the level of MLA in D. nuttallianum by high pressure liquid chromatography (HPLC) (Majak et al. 1987). Before the development of this method, larkspur toxicity was determined by rat or mouse bioassay or estimated by the total alkaloid content of the plant. However the latter method is usually used as a preliminary indicator of toxicity and it may not be strongly correlated to bioassay results (Olsen 1983). The object of the present study was to conduct a survey of the levels of MLA in D. nuttallianum growing in different rangeland habitats and thus to determine when and where it could be most hazardous to grazing cattle.

\section{Materials and Methods}

Samples were collected from 4 different sites within an $11 \mathrm{~km}$ radius of Lac du Bois, near Kamloops, B.C. Sites 1, and 2 and 3 were located in the Artemisia tridentata, Stipa-Poa and Festuca scabrella grassland zones respectively (van Ryswyk et al. 1966). Site 4 was in a transition zone between the Douglas fir (Pseudotsuga menziesii) forest zone and the Festuca scabrella upper grassland zone (Tisdale and McLean 1957). Over the last decade, cattle have been excluded from Sites 1 and 2, they have grazed Site 3 in

\footnotetext{
Authors are biochemist and research assistant, Agriculture Canada, Research Station, 3015 Ord Road, Kamloops, B.C. Canada V2B 8 A9.

The authors gratefully acknowledge the assistance of John Hall, who conducted the analysis of variance; Michael Benn, who provided alkaloid standards; and Albert van Ryswyk, who described the experimental sites in detail.

Manuscript accepted 2I December 1987.
}

the fall and Site 4 after June 1 . The soil classifications and elevations of the 4 sites are as follows: Site 1: Brown Chernozem; fine sandy, mixed, cool, subarid; moderately sloping $S$, very rocky phases; (Typic Haploboroll); 350 m elevation. Site 2: Dark Brown Chernozem; coarse loamy, mixed, cool, subarid; strongly to very strongly sloping E, very stony phases; (Haploboroll); $350 \mathrm{~m}$ elevation. Site 3: Black Chernozem; coarse loamy over compact loamy, mixed, cool, subhumid; strongly sloping SSW, very stony phases; (Udic Haploborall); $900 \mathrm{~m}$ elevation. Site 4: Dark Grey Luvisol; loamy, mixed, cool, subhumid; very strongly to very gently sloping $\mathrm{S}$, non-stony phases; (Typic Eutroboralf); $975 \mathrm{~m}$ elevation. The systems of the Canada Soil Survey Committee (1978) and, in brackets, the Soil Survey Staff (1975) were used for site classification.

Composite samples (100-200 $\mathrm{g}$ fresh weight) representing the 3 sequential stages of growth (flower bud, flower, and pod) were randomly collected at each site during 2 growing seasons ( 1986 and $1987)$ and these were stored at $-20^{\circ} \mathrm{C}$. The samples were collected from the middle of April to the beginning of June and phenology was assigned for each date of collection according to the predominating stage of growth. Samples were usually collected once per week but the number of samples per stage of growth varied with site and year depending on the duration of the phenological stage. When the aerial portions became large enough, they were divided into upper and lower parts of $15-20 \mathrm{~cm}$ in length and these were analyzed separately. A number of samples were also separated into specific parts including roots, leaves, stems, flower buds, flowers, pods and seeds. The samples were freeze-dried and ground to pass through a 2-mm screen.

The alkaloids were extracted and analyzed by ion pair HPLC as described previously (Majak et al. 1987). However, the HPLC conditions were slightly modified to permit a larger number of analyses by decreasing the retention time of MLA from $24 \mathrm{~min}$ to $12 \mathrm{~min}$. The mobile phase consisted of $4 \mathrm{mM}$ sodium hexane sulfonate in aqueous orthophosphoric acid (0.1\%)-acetonitrile (12:88). The flow rate of $0.5 \mathrm{ml} / \mathrm{min}$ created a column pressure of 58-62 atmos. The data from 2 years, 4 sites, and 3 stages of growth $(n=39)$ were statistically analyzed using the type II sums of squares for a 3-way analysis of variance in SAS GLM (Freund and Littel, 1981).

\section{Results and Discussion}

The analysis of variance revealed that the 4 larkspur sites differed significantly $(P<0.001)$ with respect to MLA concentrations in the aerial portions of $D$. nuttallianum. Higher levels of MLA were associated with larkspur sites located at higher elevations. Average levels of MLA at Site 4 (elevation $975 \mathrm{~m}$ ) for example, could be almost threefold greater than the levels of MLA at Site 1 (elevation $350 \mathrm{~m}$ ) (Fig. 1 and 2). In general, the average concentration of MLA was slightly lower $(P<0.01)$ during the bloom stage $(\bar{x}$ $=0.18 \%, \mathrm{SE}=0.01 \%)$ than during the pod $(0.21 \%)$ or flower bud $(0.21 \%)$ stages of growth. This differs from the trends reported for the total alkaloid content of tall larkspurs $(D$. barbey $i$ and $D$. occidentale) in the U.S. which showed a significant decline with advancing stages of growth (Olsen 1978, 1983). It is interesting to note however, that these species have a much longer growing season than D. nuttallianum has in B.C.

The level of MLA at Site $\mathbf{4}$ during the bud stage of growth was exceptionally high (Fig. 1). This site is known to have a history of 


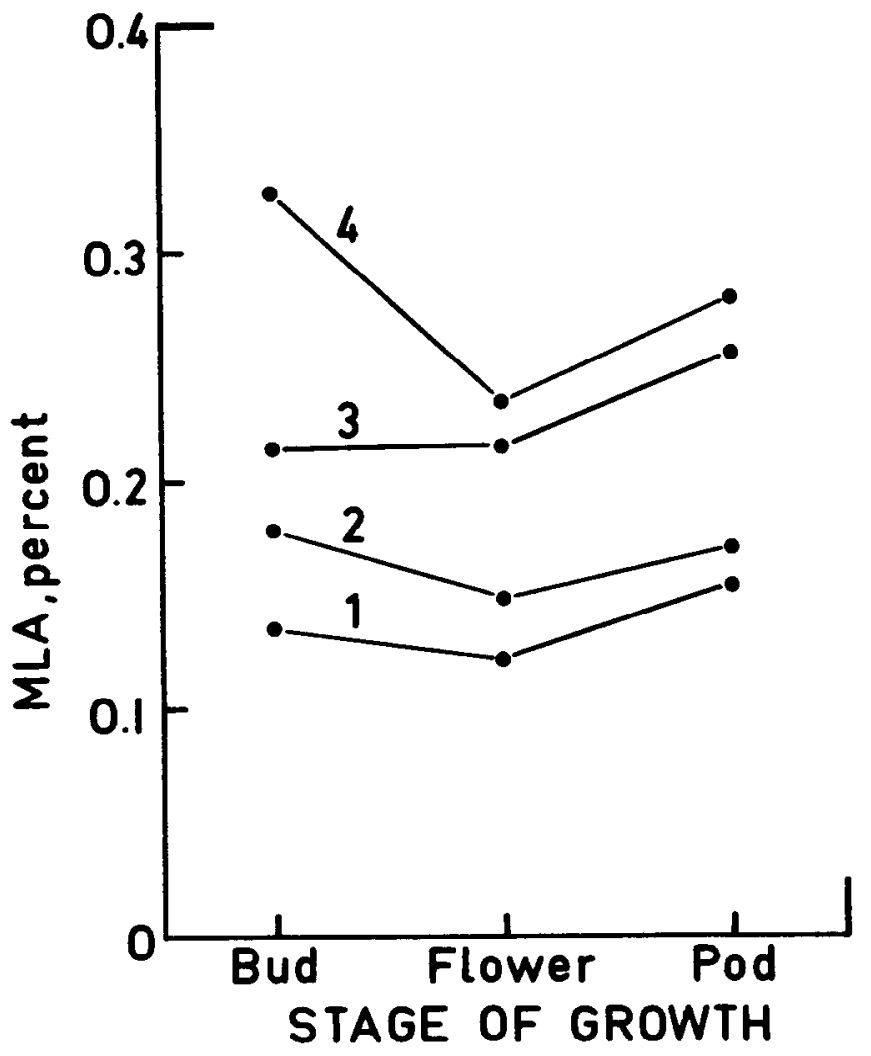

Fig. 1. Changes in methyllycaconitine ( $M L A$ ) levels in aerial growth of low larkspur at 4 sites, data averaged over 2 years and expressed on a dry matter basis. Standard errors varied from 0.01 to 0.02 except for the pod stage at site $4(S E=0.03)$.

livestock poisoning (L. Stroesser, personal communication) and our results indicate that it is particularly hazardous at early stages of $D$. nuttallianum growth. In recent memory, the worst outbreak of larkspur poisoning at Site 4 occurred during the spring of 1974 when 8 cows succumbed to the plant and at least 25 others showed signs of poisoning. Outbreaks of larkspur poisoning also occurred in other areas during that spring, which was exceptionally cool and moist (Atmospheric Environment Service 1974). An early, abundant population of larkspur was evident throughout the region and in many areas the larkspur was the predominant green foliage available. During the "green" flower bud stage of growth (with a slight bluish tinge on the bud) the plant appeared to be palatable and it was readily consumed.

There was a significant site $\times$ year interaction $(P<0.01)$ and this was attributed to the increase in the levels of MLA at Site 3 during 1987. However, the data for Site 3 in 1987 (Fig. 2) should not be misconstrued. Field observations indicated a much lower abundance of larkspur at all sites in 1987 than in 1986, and especially at Site 3, where larkspur abundance was reduced by at least $80 \%$. The grasses predominated in 1987 and the risk of poisoning was reduced because in general, the cattle prefer this forage over larkspur. Therefore the increase in MLA concentrations at Site 3 during 1987 would probably not have a practical consequence. The weather patterns during the spring of 1986 and 1987 differed considerably and this could have affected the emergence and growth of the larkspur. The month of May, which is the major growing period for $D$. nuttallianum, was on average cooler and wetter in 1986 than in 1987. The precipitation during May 1986, which was typical, was approximately twice that of May 1987 (Atmospheric Environment Service 1986, 1987). Since D. nuttallianum is a shallow-rooted perennial, the availability of soil moisture could be a critical factor determining the establishment of

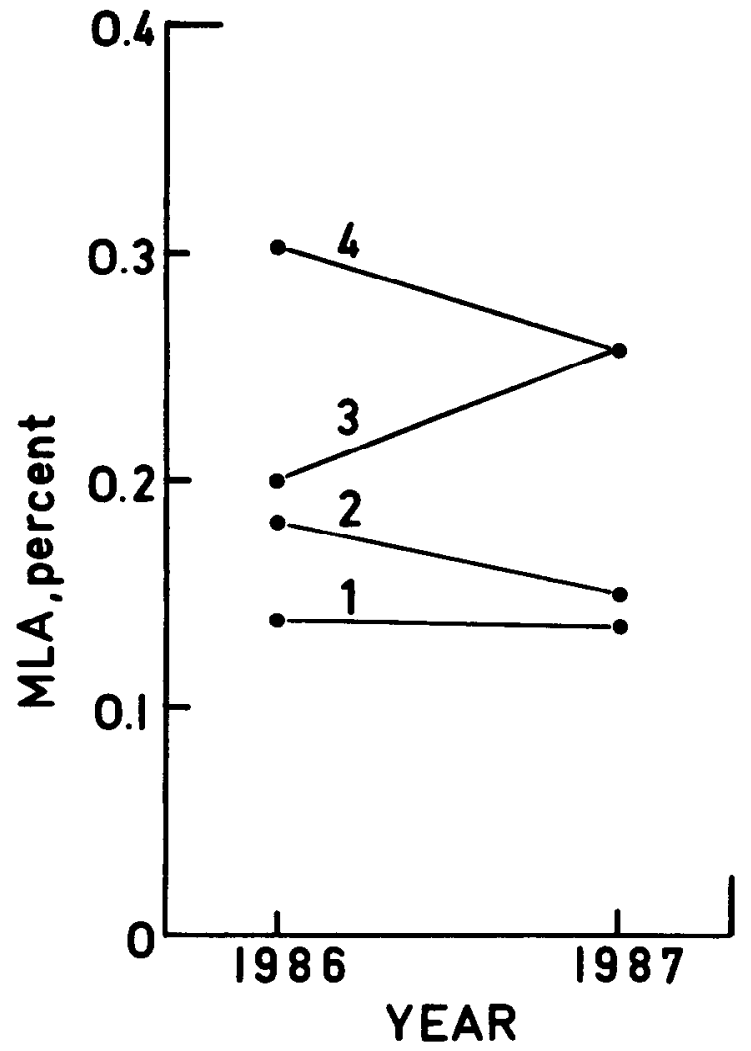

Fig. 2. Average methyllycaconitine (MLA) levels in aerial growth of low larkspur at 4 sites during 1986 and 1987, data averaged over 3 stages of growth and expressed on a dry matter basis. Standard errors varied from 0.01 to 0.02 .

larkspur seedlings in the spring and the growth of overwintered plants. The drier conditions in 1987 also resulted in a shorter growing season for $D$. nuttallianum. At Site 1 in 1987 for example, the plant progressed from the bud stage of growth to the pod stage in $4 \mathrm{wk}$. At the same site in 1986, however, the growing season lasted for $7 \mathrm{wk}$ with approximately an equal interval of growth for each phenological stage.

The variations observed with site and stage of growth prompted further analysis of the plant parts. Our preliminary data indicate that vegetative parts (leaves and stems) contain lower levels of MLA than do reproductive parts (flower buds, flowers, and pods). For example, during the bloom stage of growth at Site 3 the MLA content of vegetative parts was $0.05 \%$ for leaves and $0.22 \%$ for stems. On the other hand, the reproductive parts yielded the following MLA levels: $0.43 \%$ (flower buds), $0.37 \%$ (flowers), and $0.57 \%$ (pods). Similar trends were seen at Sites 1,2 , and 4 . The high levels of MLA in pods and pod stage plants can be partly attributed to the development of seeds which contained high levels of MLA (values ranging from $0.28 \%$ to $0.49 \%$ at Sites 1 and $2, n=4$ ). Significantly higher levels of MLA $(P<0.01)$ in the upper aerial portions $(\bar{x}=0.14 \%, \mathrm{SE}=0.015, \mathrm{n}=7)$ compared with the lower portion $(\bar{x}=0.08 \%)$ can also be explained by the fact that a greater proportion of the reproductive parts are located in the upper portion of the plant.

Nudicauline, another Delphinium diterpenoid alkaloid which is closely related to MLA (Kulanthaivel and Benn 1985), was also found in high levels in the seeds. The toxicity of nudicauline has not been determined but it contains the ester function required for neuromuscular activity (Aiyar et al. 1979, Benn and Jacyno 1983) and it only differs from MLA by having an acetate rather than methoxyl group at $\mathrm{C}_{14}$. Nudicauline was typically present in minor amounts in aerial portions equivalent to $23.6 \%(\mathrm{SE}=1.44, \mathrm{n}=39)$ of 
MLA, but in seeds nudicauline occurred at levels equivalent to $82 \%$ $(\mathrm{SE}=15.4, \mathrm{n}=4)$ of MLA. Roots were also similar in this respect. While they contained fairly low levels of MLA (0.07\% to $0.17 \%$, $\mathrm{n}=5$ ) compared with other parts, nudicauline was present at $56.4 \%$ $(S E=4.93, n=5)$ of the quantity of MLA. The presence of nudicauline in both seeds and roots was confirmed by using an authentic standard to enhance the nudicauline peak on HPLC. The distribution of MLA and nudicauline in D. nuttallianum merits further investigation.

It is apparent that a grazing animal can ingest variable quantities of MLA depending on the part and the quantity of plant material consumed. Observations of cattle grazing low larkspur revealed that in the first pass through a stand, the animals select only the upper growth of the plant (L. Stroesser, personal communication). To evaluate the potential toxicity of the animals' diet, we collected large composite samples (>100 plants) to simulate the ingested part of the larkspur. Two separate samples were collected from Site 4 on the same day when plants were in a transitory stage between flower bud and flower. One sample was composed of the top $10 \mathrm{~cm}$ of plants that were predominantly in the bud stage of growth; it gave a MLA level of $0.32 \%$. The other sample was made up of the top $20 \mathrm{~cm}$ of plants representing the flowering stage and yielded a MLA level of $0.25 \%$. Another such experiment was carried out at the same site when D. nuttallianum was in full bloom. This time the samples were collected 2 days apart but both samples were a composite of flowering plants. The earlier sample consisted of the top $20 \mathrm{~cm}$ of plant material giving a MLA level of $0.16 \%$, while the second sample consisted of the top $10 \mathrm{~cm}$ and had a MLA level of $0.31 \%$. In future studies, information on the grazing habits of livestock must be integrated with MLA distribution data to assess the potential danger of $D$. nuttallianum to grazing livestock accurately. Studies should also be conducted to determine the effect of seasonal climate on the emergence and growth of $D$. nuttallianum.

In summary, the present studies indicate that indicates that stands of $D$. nuttallianum at higher elevations are more likely to be hazardous to grazing cattle than those at lower elevations. On a dry weight basis, the levels of MLA were fairly constant throughout the growing season, not showing a decrease with advancing stages of growth. However, D. nuttallianum may be more hazardous to range cattle at earlier stages of growth when it is more succulent and palatable.

\section{Literature Cited}

Alyar, V.N., M.H. Benn, T. Hanna, J. Jacyno, S.H. Roth, and J.L. Wilken. 1979. The principal toxin of Delphinium brownii Rydb. and its mode of action. Experientia 35:1367-1368.
Atmospheric Environment Service. 1974, 1986, 1987. Monthly record. Meteorological observations in Western Canada. May. Environment Canada, Atmos. Environ. Serv., Downsview, Ontario.

Benn, M.H., and J.M. Jacyno. 1983. The toxicology and pharmacology of diterpenoid alkaloids, p. 153-210. In: S.W. Pelletier (ed.). Alkaloids: chemical and biological perspectives. Vol. 1. John Wiley and Sons Inc., New York.

Canada Soil Survey Committee, Subcommittee on Soll Claselfication. 1978. The Canadian system of soil classification. Can. Dep. Agr. Pub. 1646. Supply and Services Canada, Ottawa, Ontario.

Cronin, E.H., and D.B. Nielsen. 1978. Tall larkspur and cattle on high mountain ranges, p. 521-534. In: R.F. Keeler, K.R. Van Kampen, and L.F. James (eds.). Effects of Poisonous Plants on Livestock. Academic Press, New York.

Freund, R.J., and R.C. Littell. 1981. SAS for Linear Models, Guide to the ANOVA and GLM Procedures. SAS Institute Inc., Cary, North Carolina.

Hitchcock, C.L., and A. Cronquist. 1964. Part 2, Salicaceae to Saxifragaceac. In: Vascular Plants of the Pacific Northwest. University of Washington Press. Seattle.

Jennings, K.R., D.G. Brown, and D.P. Wright Jr. 1986. Methyllycaconitine, a naturally occurring insecticide with a high affinity for the insect cholinergic receptor. Experientia 42:611-613.

Kulanthaivel, P., and M.H. Benn. 1985. Diterpenoid alkaloids from Delphinium nudicaule Torr. and Gray. Heterocycles 23:2515-2520.

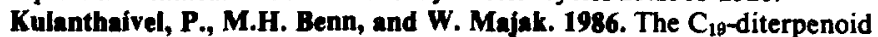
alkaloids of Delphinium bicolor. Phytochemistry 25:1511-1513.

Looman, J., W. Majak, and S. Smoliak. 1983. Stock-poisoning plants of western Canada. Contribution 1982-7E. Agriculture Canada. Ottawa, Ontario.

Majak, W., R.E. McDiarmid, and M.H. Benn. 1987. Isolation and HPLC determination of methyllycaconitine in a species of low larkspur ( $\mathrm{Del}$ phinium nuttallianum). J. Agr. Food Chem. 35:800-802.

Nation, P.N., M.H. Benn, S.H. Roth, and J.L. Wilkens. 1982. Clinical signs and studies of the site of action of purified larkspur alkaloid, methyllycaconitine, administered parenterally to calves. Can. Vet. J. 23:264-266.

Olsen, J.D. 1978. Larkspur toxicosis: a review of current research. p. 535-543. In: R.K. Keeler, K.R. Van Kampen, and L.F. James (eds.). Effects of Poisonous Plants on Livestock. Academic Press, New York.

Olsen, J.D. 1983. Relationship of relative total alkaloid concentration and toxicity of duncecap larkspur during growth. J. Range Manage. 36:550-552.

Soil Survey Staff. 1975. Soil taxonomy USDA Hdbk. 436. U.S. Government Printing Office, Washington, D.C.

Tisdale, E.W., and A. MeLean. 1957. The Douglas fir zone of southern British Columbia. Ecol. Monogr. 27:247-266.

van Ryswylk, A.L., A. McLean, and L.S. Marchand. 1966. The climate, native vegetation, and soils of some grasslands at different elevations in British Columbia. Can. J. Plant Sci. 46:35-49. 